\title{
PENGARUH PENAMBAHAN ELECTRICAL MUSCLE STIMULATION (EMS) PENINGKATAN TONUS OTOT PADA PENDERITA DD
}

\author{
Agus Widodo dan BJ. Zia Yucca Praditya \\ Prodi Fisioterapi Fakultas Ilmu Kesehatan \\ Universitas Muhammadiyah Surakarta \\ Jl. A Yani Tromol Pos I, Pabelan, Surakarta
}

\begin{abstract}
Delayed Development (DD) is the classification of characteristics of children which is showed a significant delay in one or more domains of cognitive development, emotional or physical. The problems that arise in the $D D$ are hypotonus of the muscles that cause delays in functional abilities of children. The purpose of this study was to determine the influence of Electrical Muscle Stimulation (EMS) to increase muscle tone of DD patients. Quasi-experimental research method using two pre and post-test group design. Sample of this research was 12 children 1-3 years of age. Measurement of muscle tone using a sphygmomanometer before and after treatment for 4 weeks. The effect measured using Wilcoxon tes and the different effect measured using Mann Whitney test. Wilcoxon test result showed that the effect of electrical muscle stimulation on muscle tone was seen from the right quadriceps $p$ value $(p=0.026)$, the left quadriceps $(p=0.024)$, right tibialis anterior $(p=0.024)$ and left tibialis anterior $(p=0.024)$. It can be concluded that there is an effect of Electrical Muscle stimulation on increasing the muscle tone in people with $D D$.
\end{abstract}

Keywords: EMS and hypotonus, Delayed Development

\section{PENDAHULUAN}

Proses tumbuh kembang pada anak tidak lepas dari pengaruh neurosensomotorik. Hal ini dikenal dalam bentuk perkembangan dan selanjutnya berpengaruh terhadap motorik dan volunterrnya. Dalam perkembangan gerak itu sendiri, meliputi adanya proses yang diawali dari gerak primitive atau reflex dan fisiologis volunter adaptasi. Hal inilah yang lebih penting dilihat pada setiap perkembangan pada anak seperti melihat pertumbuhan motorik anak. Tetapi salah satu masalah utama tumbuh kembang pada bayi apabila terjadi suatu Delayed developmet (DD) atau keterlambatan dalam tumbuh kembang, sehingga proses suatu perkembangan anak akan menjadi terhambat.

Delayed developmet (DD) adalah klasifikasi ciri anak menunjukkan keterlambatan signifikan dalam satu atau lebih domain perkembangan kognitif, emosional atau fisik (Christine and Delgado, 2007). Indonesia khusus- 
nya di Jakarta, telah dilakukan Stimulasi Deteksi dan Intervensi Dini Tumbuh Kembang Anak (SSDIDTK). Hasilnya, dari 476 anak yang diberi pelayanan SDIDTK, ditemukan 57 $(11,9 \%)$ anak dengan kelainan tumbuh kembang. Adapun lima jenis kelainan tumbuh kembang yang paling banyak dijumpai adalah $D D$ (tumbuh kembang yang terlambat) sebanyak 22 anak, Global Delayed Development sebanyak 4 anak, gizi kurang sebayak 10 anak, Mikrochepali sebanyak 7 anak dan anak yang tidak mengalami kenaikan berat badan dalam beberapa bulan terakhir sebanyak 7 anak (Iwan, 2011).

Salah satu masalah pada penderita $D D$ yakni terdapat hypotonus. Hypotonus adalah penurunan massa otot dan biasanya terjadi suatu peningkatan mobilitas sendi (Rollings, 2005). Tonus otot menurun disebabkan karena oleh menurunnya impuls dari otak ke otot melalui saraf perifer (Jordan, 2005). Akibatnya mengalami kesulitan dalam beraktifitas dan melakukan kemampuan fungsional.

Menanggulangi hypotonus banyak metode-metode yang digunakan berupa manual terapi atau metode lainnya. Peneliti menggunakan Electrical Muscle Stimulation (EMS) sebagai metode dalam menangani hypotonus. EMS menggunakan arus listrik yang dapat merangsang proses $\mathrm{Na}^{+}$dan $\mathrm{K}^{+}$ dalam mekanisme potensial aksi dengan harapan akan terjadi peningkatan tonusnya sehingga dapat terjadi peningkatan kemampuan otot pada anak
DD. Stimulasi listrik neuromuskuler menciptakan tetani otot melalui aktivasi fiber motor menuju otak (Doucet et al., 2012).

Berdasarkan latar belakang yang telah diuraikan di atas, maka peneliti ingin mengambil judul pengaruh EMS terhadap peningkatan tonus pada penderita DD di Klinik Children's House Yogyakarta. Tujuan dari penelitian ini adalah mengetahui pengaruh EMS terhadap peningkatn tonus otot penderita $D D$.

\section{METODE PENELITIAN}

Suatu penelitian dengan quasi eksperimen dengan design pre and post test with control group. Design ini melibatkan suatu tindakan dan dua kelompok di observasi sebelum dan sesudah melakukan tindakan, bertujuan untuk melihat adanya pengaruh sesudah diberikan perlakuan.

Hasil dari perlakuan dibandingkan dengan kelompok kontrol. Analisis data menggunakan SPSS Versi 17.0, data dilakukan pengujian dengan nonparametric menggunakan Wilcoxon untuk mengetahui pengaruh masingmasing kelompok yang diberi perlakuan dan uji Mann Whitney test untuk melihat adanya beda pengaruh pada kedua kelompok.

\section{HASIL DAN PEMBAHASAN}

Penelitian di Klinik Children House Bantul, respondennya adalah penderita $D D$ dengan hipotonus. 
Jumlah populasi sebanyak 49 responden, sebanyak 12 memenuhi kreteria dan bagi dua kelompok yaitu kelompok perlakuan I (Massage baby, exercise therapy dan $E M S$ ) sebanyak 6 anak dan kelompok II kontrol (massage baby, exercise therapy) sebanyak 6 anak. Parameter yang di ukur adalah pada tonus otot quadriceps kanan, quadriceps kiri, tibialis anterior kanan dan tibialis anterior kiri dengan menggunakan alat ukur spignomanometer.

Tabel 1. Karakteristik Usia Responden

\begin{tabular}{lcc}
\hline Usia & Kelompok Perlakuan & Kelompok Kontrol \\
\hline $1,0-2,0$ tahun & 3 & 6 \\
\hline $2,1-3,0$ tahun & 3 & 0 \\
\hline
\end{tabular}

Hasil Mean tonus otot pre dan post pemberian electrical stimulation pada

penderita $D D$ dan pada kelompok kontrol (massage baby dan exercise therapy).

Tabel 2. Karakteristik Tonus Otot Kelompok Perlakuan

\begin{tabular}{lccc}
\hline Variabel & Mean Pre & Mean Post & Selisih Mean \\
\hline Quadriceps kanan & 55.33 & 63.33 & 8,00 \\
Quadriceps kiri & 51.00 & 58.66 & 7.33 \\
Tibialis Anterior kanan & 51.33 & 57.66 & 7.33 \\
Tibialis Anterior kiri & 48.66 & 54.33 & 5.67 \\
\hline
\end{tabular}

Tabel 3. Karakteristik Tonus Otot Kelompok Kontrol

\begin{tabular}{lccc}
\hline Variabel & Mean Pre & Mean Post & Selisih mean \\
\hline Quadriceps kanan & 46 & 47.66 & 1.66 \\
Quadriceps kiri & 44.33 & 45.66 & 1.33 \\
Tibialis Anterior kanan & 44.66 & 46.00 & 1,34 \\
Tibialis Anterior kiri & 44.33 & 45.66 & 1.33 \\
\hline
\end{tabular}

Berdasarkan hasil mean pre-post kelompok perlakuan ada nilai selisih, menunjukan ada pengaruh pemberian EMS terhadap tonus otot dan hasil mean pre-post kelompok kontrol adanya nilai selisih serta ada pengaruh. 
Tabel 4. Hasil Uji Wilcoxon pada Kelompok Perlakuan

\begin{tabular}{lcc}
\hline \multicolumn{1}{c}{ Variabel } & P Value & Kesimpulan \\
\hline Quadriceps kanan & 0.026 & H0 ditolak \\
Quadriceps kiri & 0.024 & H0 ditolak \\
Tibialis Anterior kanan & 0.024 & H0 ditolak \\
Tibialis Anterior kiri & 0.026 & H0 ditolak \\
\hline
\end{tabular}

Dari hasil pengujian didapatkan hasil nilai $p$ value lebih kecil dari bilangan 0,05 dapat diartikan ada pengaruh penambahan EMS dalam peningkatan tonus otot pada anak $D D$.

Tabel 5. Hasil Uji Wilcoxon pada Kelompok Kontrol

\begin{tabular}{lcc}
\hline \multicolumn{1}{c}{ Variabel } & P Value & Kesimpulan \\
\hline Quadriceps kanan & 0.025 & H0 ditolak \\
Quadriceps kiri & 0.046 & H0 ditolak \\
Tibialis Anterior kanan & 0.046 & H0 ditolak \\
Tibialis Anterior kiri & 0.046 & H0 ditolak \\
\hline
\end{tabular}

Dari hasil pengujian didapatkan hasil nilai $p$ value lebih kecil dari bilangan 0,05 diartikan ada pengaruh pemberian massage baby dan exercise therapy pada tonus otot pada penderita $D D$.
Uji beda pengaruh antara kelompok perlakuan EMS dan kelompok kontrol terhadap tonus menggunakan

Tabel 6 Man Whitney Sebelum dan Sesudah Perlakuan Kelompok Kontrol dan Eksperimen

\begin{tabular}{lcccl}
\hline \multicolumn{1}{c}{ Variabel } & $\begin{array}{c}\text { Mean } \\
\text { Perlakuan }\end{array}$ & $\begin{array}{c}\text { Mean } \\
\text { Kontrol }\end{array}$ & P value & Kesimpulan \\
\hline Quadriceps kanan & 8,00 & 1.66 & 0,003 & Ada beda \\
Quadriceps kiri & 7.33 & 1.33 & 0,003 & Ada beda \\
Tibialis Anterior kanan & 7.33 & 1.34 & 0,003 & Ada beda \\
Tibiais Anterior Kiri & 5.67 & 1.33 & 0,003 & Ada beda \\
\hline
\end{tabular}


Hasil uji beda dengan Man Whitney pada kelompok perlakuan dan kelompok kontrol pada nilai meannya kelompok perlakukan lebih besar yang berarti adanya pengaruh yang lebih baik dengan penambahan EMS terhadap peningkatan nilai mean kekuatan otot yang hypotonus pada $D D$.

Karakteristik responden dari usia jumlah terbanyak pada usia 1 - 3 tahun. Usia 1 - 2 tahun anak mampu melakukan kemampuan fungsional seperti merangkak, berdiri, dan berjalan dan pada usia 2 - 3 tahun anak mampu berlari dan meloncat.

Tonus otot pada responden dari usia menunjukan hasil yang rendah dibandingkan dengan tonus otot dengan anak normal, dari hasil pengukuran sphygmomanometer. Anak hipotonus dan anak normal memiliki rentan yang cukup jauh dengan nilai tonus terbanyak adalah $44-46 \mathrm{mmHg}$.

Hasilnya berpengaruh dengan penambahan EMS pada tonus otot $D D$. Menurut penelitian Doucet (2012) tentang pengaruh Neuromuscular electrical stimulation (NMES) terhadap kemapuan fungsi otot skelet. EMS merupakan suatu cara penggunaan energi listrik yang merangsang sistem saraf melalui permukaan kulit (Parjoto, S. 2006). Menurut Cameron (2009), bahwa pemberian Transcutaneus Electrical Nerve Stimuation (TENS) arus byphasic dengan intensitas yang rendah dan durasi yang rendah 200 - 300 ms dapat menghasilkan cukup stimulus dalam proses potensial aksi di saraf dan dediinervasi otot. Proses potensial aksi akan terjadi fase depolarisasi diikuti oleh repolarisasi yang akan menghasilkan rangsangan menuju otak sehingga terjadi suatu kontraksi otot yang akan mengakibatkan tonus meningkat .

Mekanisme peningkatan tonus jika kutup positif aktif maka akan mengaktifasi serabut otot berdiameter besar, kemudian berdampak potensial aksi pada kutub negatif, ini disebut proses depolarisasi. Pada proses repolarisasi, akan terjadi pertukaran ion $\mathrm{Na}^{+}$ dan $\mathrm{Ka}^{+}$, apabila ion $\mathrm{Ka}^{+}$dan $\mathrm{Na}^{+}$berada di dalam membrane secara bersamaan akan menghasilkan rang-sangan pada motor unit menuju otak. Rangsangan tersebut akan kembali ke jaringan dan akan terjadi kontraksi otot secara berulang, hal inilah yang dimanfatkan dalam upaya mening-katkan tonus otot (William, 2005).

Tujuan peningkatan tonus otot pada otot quadriceps dan tibialis anterior adalah untuk meningkatkan stabilisasi pada knee khususnya penguatan grup otot fleksornya dan ankle khususnya dalam peningkatan grup otot dosifleksor dengan harpan secara kemampuan fungsional pada saat mempersiapkan berdiri maupun berjalan.

Adanya rangsangan secara kontinue akan meningkatkan dan menguatkan sinaps dari jaringan ke otak akan berjalan dengan baik, sehingga motor unit pada muscle spindle jumlah akan meningkat. Pada kelompok 
kontrol terhadap peningkatan tonus otot pada penderita $D D$. Menurut Haakana (2008), pengaruh massage terhadap tonus otot menunjukkan ke tidak maknaan terhadap peningkatan tonus otot tetapi sangat efektif dalam rileksasi otot. Menurut Barclay (2007), pengaruh obat oxondlorone dan ditambahkan exercise therapy terhadap peningkatan kekuatan otot dan massa otot pada anak penderita luka bakar, hasilnya adanya signifikan pada kekuatan otot dan massa otot pada anak tersebut. Mekanisme ini khususnya exercise therapy akan berdampak pada serabut intrafusal dan extrafusal. Adanya stimulasi maka akan merangsang serabut intrafusal (muscles spindle) menghasilkan impuls yang menuju spinal cord hal ini bertujuan untk memberikan rangsangan pada saraf perifernya. Terjadinya Adaptasi akibat dari exercise therapy secara kontinue maka akan mempengaruhi motor unit (serabut extrafusal) yaitu pada sarkomer sehingga akan terjadi peningkatan aktivitas aktinmyosin terjadi peningkatan tonus otot (Wilmord \& David, 1994)

Secara nilai mean pada ke dua kelompok ada beda pengaruh. Hal dapat dijelaskan bahwa dengan pemberian $E M S$ yang akan merangsang aktivasi pada ion $\mathrm{Na}^{+}$dan $\mathrm{K}^{+}$pada membran otot yang akan mehasilkan proses pontensial aksi depolariasi dan repolarisasi. Proses tersebut memberikan penanan yang penting dalam fisiologis mekanisme kontraksi otot. Dengan adanya exercise therapy secara kontinue mengstimulasi akan menguatkan dan menambah sinaps pada motor unit dan meningkatkan aktifitas pada tingkat aktin-myosin (sarkomer). Mekanisme tersebut dimanfaatkan dalam memberikan terapi pada kondisi otot yang mengalami hypotonus khsususnya anak $D D$ di mana perlu adanya bentuk rangsangan pada neuro muskulerjunction.

Keterbatasan penelitian ini adalah dalam pengukuran tonus otot sebaiknya menggunakan Electro Myography. Peneliti tidak dapat mengontol dan melihat latihan anak yang dilakukan orang tua di rumah, sehingga peneliti tidak mengatahui aktivitas yang dilakukan anak sehari-hari

\section{KESIMPULAN}

Pemambahan EMS pada otot hypotonus penderita DD anak-anak bermakna dalam peningkatan tonus otot. Berdasarkan pelaksanaan dari hasil penelitian yang telah dilakukan maka peneliti meberikan saran - saran. Pada Orang tua responden untuk melatih anak secara efektif agar mendapatkan peningatan tonus otot secara baik dan kemampuan fungsional anak akan meningkat. Untuk memperkuat hasil penelitian ini, disarankan dilakukan penelitian lanjut dengan menambah jumlah sampel, menambah variasi dari variabel dan metode penelitian lainnya seperti studi kasus, cross sectional dan lain - lain. Usia responden lebih dibatasi sehingga tidak terjadi rentang yang jauh 


\section{DAFTAR PUSTAKA}

Barclay, L. 2007. Oxandrolone Plus Exercise Increases Muscle Mass, Strength in Children With Severe Burns. Medscape Edication

Cameron, H Michelle and Verma, D. 2009. Electrophysical Agents.

Christine, F, D., 2007. Identification of Early Risk Factor of Delay Development. Exeptionality. Journal of Physicology. (15) 2 199-136.

Doucet, B.M., 2012. Neuromuscular Electrical Stimulation for Skeletal Muscle Function. Yale Journal of Biology and Medicine 85 201-15.

Haakana, P. 2008. The Acute Effects of Massage on Muscle Tone and Perceived Recovery. Thesis. University of Jyv skyl

Iwan. 2011. Deteksi Dini Tumbuh Kembang. http://kesehatan-balita-1plus. blogspot.com/2011/05/ihwansidiq-deteksi-dini-tumbuh kembang.html. Diakses pada 21 Januari 2013.

Rollings. 2005. Rebound Therapy Handbook. Rebound Therapy for Special Education Needs. 2 day course. Newcastle.

William, E.P., 2005. Therapeutic Modalities in Rehabilitation. Third Edition. United States of America. The McGraw-Hill Companies.

Wilmord, H. J and Costill. D.L., 1994. Physiology of Sport Exercise. Second Edition. USA. 